\title{
A penta-substituted pyridine alkaloid from the rhizome of Jatropha elliptica (Pohl) Muell. Arg. is active against Schistosoma mansoni and Biomphalaria glabrata
}

\author{
Aldenir Feitosa dos Santos • Saskya Araújo Fonseca - Fernanda Andrade César • \\ Mônica Camelo Pessoa de Azevedo Albuquerque • José Valfrido Santana • \\ Antônio Euzébio Goulart Santana
}

Received: 12 September 2013 / Accepted: 26 December 2013 /Published online: 6 February 2014

(C) The Author(s) 2014. This article is published with open access at Springerlink.com

\begin{abstract}
Jatropha elliptica is a shrub distributed throughout the north and west of Brazil and reputedly possesses a wide range of therapeutical properties. The roots of this plant possess molluscicidal activity and contain terpenoids, coumarin, lignoid, steroids and alkaloid. In the present study, we assessed the schistosomicidal, miracicidal and cercaricidal activities (against Schistosoma mansoni) and molluscicidal activities (against adults and egg masses of Biomphalaria glabrata) of the alkaloid diethyl 4-phenyl-2,6-dimethyl-3,5pyridinedicarboxylate, isolated from the ethanol extract of the rhizome of $J$. elliptica, have been determined. The alkaloid was $100 \%$ lethal to adult schistosomes within 4 days at a concentration of $50 \mu \mathrm{g} / \mathrm{mL}$. Alterations were observed in the schistosome tegument occasioned by treatment with the alkaloid, such as formation of vesicles and vacuolisation. The extent of tegumental damage of the worm was proportional to the time of incubation and to the concentration of compound. The alkaloid also exhibited a potent cercaricidal activity $\left(\mathrm{LC}_{100}=2 \mu \mathrm{g} / \mathrm{mL}\right)$; it was totally ineffective against
\end{abstract}

\footnotetext{
A. F. dos Santos · S. A. Fonseca

Grupo Estudo de Compostos Naturais Bioativos, Centro

Universitário Cesmac, 57051-160 Maceió, AL, Brazil

\author{
A. F. dos Santos \\ Grupo de Pesquisa em Química, Universidade Estadual de Alagoas, \\ 57312-270 Arapiraca, AL, Brazil
}

F. A. César · M. C. P. de Azevedo Albuquerque · J. V. Santana Laboratório de Imunologia e Esquistossomose Experimental, Laboratório de ImunopatologiaKeizoAsami, Universidade Federal de Pernambuco, 50670-901 Recife, PE, Brazil

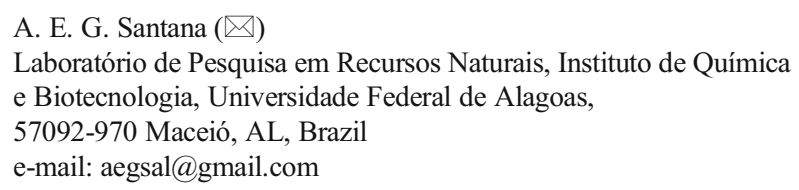

miracicidal forms of the parasite. Moreover, the alkaloid presented strong activity against adult snails $\left(\mathrm{LC}_{90}=36.43 \mu \mathrm{g} /\right.$ $\mathrm{mL}$ ) but was inactive against their egg masses. It is observed then the potential of this compound for the development of new therapies for the treatment of schistosomiasis.

\section{Introduction}

Schistosomiasis is the second most prevalent tropical disease affecting more than 200 million people worldwide (WHO 2005; Rollemberg et al. 2011). Moreover, the prevalence of this disease is increasing in many areas of the world owing to the poor level of basic sanitation and the low social and economic status of the respective populations. In Brazil, eight million people from endemic regions stretching from the north to the south-east of the country are infected with this chronic debilitating disease (Katz and Peixoto 2000).

The two main approaches for the control of schistosomiasis currently involve reducing the transmission of the disease and applying chemotherapy in identified cases, and this situation is unlikely to change until a suitable vaccine becomes available.

Praziquantel is currently the drug of choice for the treatment of schistosomiasis. However, this drug does not prevent reinfections, is inactive against juvenile schistosomes and has a limited effect as well on already developed liver and spleen lesions. In addition, there is a considerable concern about the development of praziquantel resistance of some strains. These reports emphasise the need of developing new schistosomicidal drugs for the treatment of this neglected tropical disease (Magalhães et al. 2009, 2010; Miranda et al. 2012).

One strategy that has been used to regulate schistosomiasis is through control of the mollusc that acts as the intermediate 
host. Molluscicides currently in use are typically synthetic compounds (copper sulphate or carbonate, niclosamide and pentachlorophenate), although a number of agents of natural origin have been reported (Luna et al. 2005; Shukla et al. 2006). Control of schistosomiasis using a molluscicide would be far more effective if the agent also possessed miracidicidal and cercaricidal activities. Although both miracidia and cercariae are short-lived (lifespan of $12-48 \mathrm{~h}$ ), their elimination is not trivial. In the case of cercariae, for example, multiple treatments of infested sites are necessary since infected molluscs continually shed new cercariae into the water.

The use of drugs derived from plants, fungi, bacteria and marine organism has a long tradition in medicine. Plants constitute a rich source of bioactive chemicals. In addition, herbal medicines are generally more accessible and affordable and are an important part of the culture and traditions of many populations (Pontin et al. 2008; Koné et al. 2012). The interest in medicinal plants as new sources of antiparasitic drugs is rising (Ferreira et al. 2011). In the past years, many studies have been undertaken to assess the potential of medicinal extracts against parasitic diseases (Elango and Rahuman 2011; Ghosh et al. 2011).

Various natural compounds have been shown to be toxic to miracidia and cercariae (Santos et al. 2007; Kamel et al. 2010), and some plants were reported to possess components that can inhibit the penetration of cercariae through human skin (DeCarvalho et al. 1998). Crude aqueous extract of Zingiber officinale (Mostafa et al. 2011) and pure compounds as artemether (Abdul-Ghani et al. 2011) and dihydroartemisinin (Li et al. 2011) have showed in vivo schistosomicidal effects, but so far, no new drug has been marketed for the treatment of schistosomiasis (Miranda et al. 2012).

During our search of the Brazilian flora for extracts and compounds that could be used to control Biomphalaria glabrata, we have been able to demonstrate that the roots of Jatropha elliptica (Pohl) Muell Arg. (Euphorbiaceae) possess molluscicidal activity (Santos and Sant'Ana 1999). J. elliptica is an annual shrub (Fig. 1) distributed throughout the north and west of Brazil and reputedly possesses a wide range of therapeutical properties (Lima et al. 2006; Sabandar et al. 2013). The diterpenoids jatrophone (1) and jatropholones A and B (2 and 3), the ester pentatriacontanyl ferulate (4), the coumarin fraxetin (5), the coumarin lignoid propacin (6), the triterpenoid acid 3-O-acetyl aleuritolic acid (7) and a mixture of steroids $\beta$-sitosterol and stigmasterol have been previously isolated from the rhizome of J. elliptica (Goulart et al. 1993). More recently, a penta-substituted pyridine, namely diethyl 4phenyl-2,6-dimethyl-3,5-pyridinedicarboxylate (8) has been identified in the roots of the plant (Fig. 2) (Marquez et al. 2005; Santos et al. 2005).

In the present paper, we report the evaluation of schistosomicidal, miracidicidal or cercaricidal activities against Schistosoma mansoni and/or molluscicidal activity



Fig. 1 Jatropha elliptica (Pohl) Muell Arg. cultivated in greenhouse

against Biomphalaria glabrata of the alkaloid diethyl 4phenyl-2,6-dimethyl-3,5-pyridinedicarboxylate (pentasubstituted pyridine alkaloid) isolated from the ethanol extract of the rhizome of J. elliptica.

\section{Material and methods}

Plant material, extraction and fractionation

Roots of J. elliptica Muel. Arg. were collected in the state of Goiás, Brazil. Plant material was authenticated by Professor José Elias de Paula and a voucher specimen [JEP 1863 (UB)] is deposited in the herbarium of Universidade de Brasilia, Brasilia DF. Powdered, air-dried root material was extracted and fractionated as described earlier (Santos et al. 2005).

\section{Snails and schistosomes}

A colony of B. glabrata was maintained at the Departamento de Parasitologia (Universidade Federal de PernambucoUFPE, Recife, PE, Brazil) as described previously Santos and Sant'Ana 1999. Adult snails (shell diameters 19$25 \mathrm{~mm}$ ) and egg capsules were employed in bioassay experiments. The BH strain (Belo Horizonte, MG, Brazil) of S. mansoni was routinely maintained at the Laboratório de Imunopatologia Keiko Asami (UFPE) by passage through B. glabrata and mice (El-Beshbishi et al. 2013). 
Fig. 2 Compounds isolated from ethanol extract of the rhizome of J. elliptica

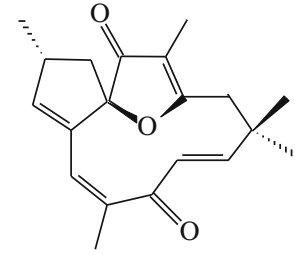

1<smiles>CCCCCCOC(=O)/C=C/c1ccc(O)c(OC)c1</smiles>

4

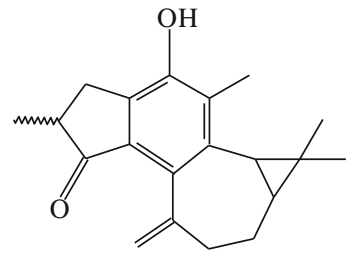

$2-2 \beta$ - Me; $3-2 \alpha-$ Me<smiles>COc1cc2ccc(=O)oc2cc1O</smiles>

5<smiles>COc1cc([C@H]2Oc3c(OC)cc4ccc(=O)oc4c3O[C@@H]2C)ccc1O</smiles>

6

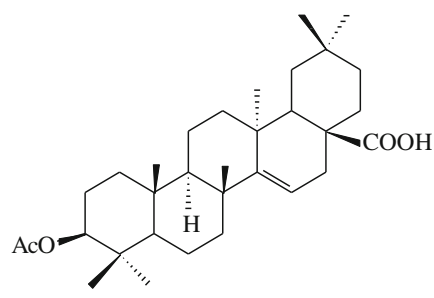

7<smiles>CCOC(=O)c1c(C)nc(C)c(C(=O)OCC)c1-c1ccccc1</smiles>

8

Preparation of working solutions for the bioassays

Adult schistosome bioassay A stock solution $(400 \mu \mathrm{g} / \mathrm{mL})$ was prepared for each sample by dissolving an aliquot (8 mg) in dimethyl sulphoxide (DMSO; $200 \mu \mathrm{L}$ ) and adding RPMI-1640 medium to a final volume of $20 \mathrm{~mL}$. Appropriate aliquots of the stock solution were diluted with parasite culture medium to yield concentrations of 200, 100, 50 and $10 \mu \mathrm{g} /$ $\mathrm{mL}$. Six replicates of each bioassay were carried out for each sample concentration (Mohamed et al. 2005).

Miracidia bioassay A stock solution (1 $\mathrm{mg} / \mathrm{mL})$ was prepared for each sample by dissolving an aliquot $(15 \mathrm{mg})$ in DMSO $(150 \mu \mathrm{L})$ and adding dechlorinated water to a final volume of $15 \mathrm{~mL}$. Samples $(150 \mu \mathrm{L})$ were typically assayed in duplicate at concentrations of 1, 10 and $100 \mu \mathrm{g} / \mathrm{mL}$ (Mohamed et al. 2005).

Cercariae bioassay A stock solution $(200 \mu \mathrm{g} / \mathrm{mL})$ was prepared for each sample by dissolving an aliquot $(3 \mathrm{mg})$ in
DMSO $(150 \mu \mathrm{L})$ and adding dechlorinated water to a final volume of $15 \mathrm{~mL}$, as previously described (Santos et al. 2007).

Adult snail bioassay Stock solutions for bioassays were prepared according to a previously described protocol (Santos et al. 2010).

Egg mass bioassay Test solutions were prepared according to a previously described protocol (Santos and Sant'Ana 2001).

Protocols for the bioassays

Schistosomicidal activity Strict aseptic techniques were employed throughout the experiments Mercer and Chapell (1985). Two adult schistosomes, paired or unpaired, in parasite culture medium were placed into one well of a multi-well plastic tissue culture plate, an appropriate aliquot of sample solution was added, and the plates were incubated at $37 \pm 1{ }^{\circ} \mathrm{C}$ in a humid atmosphere containing $5 \% \mathrm{CO}_{2}$. The viability of 
the worms was observed under an inverted microscope each day until the fifth day after sample addition. Schistosomes were considered dead when no movement could be detected over a 3-min observation period. Positive controls $(10 \mu \mathrm{g} / \mathrm{mL}$ praziquantel [Sigma]) and negative controls (RPMI-1640 medium containing $1 \% v / v$ DMSO) were included in every experiment, and a minimum of 30 schistosomes were employed in the assay of each treatment and control group.

Miracidicidal activity Twenty miracidia were exposed to each concentration of a sample in multi-well plates as described previously (Mohamed et al. 2005) together with positive controls $(0.1 \mu \mathrm{g} / \mathrm{mL}$ niclosamide $)$ and negative controls (dechlorinated water containing $1 \% v / v$ DMSO).

Cercaricidal activity Approximately 500 freshly released cercariae suspended in dechlorinated water were placed into a $25-\mathrm{mL}$ beaker and an appropriate aliquot of sample solution was added as previously described (Santos et al. 2007).

Molluscicidal activities Activities against adult snails and egg masses were evaluated according to established procedures (Santos and Sant'Ana 2001; Santos et al. 2010; Teixeira et al. 2012).

Statistical methods

$\mathrm{LC}_{10}, \mathrm{LC}_{50}$ and $\mathrm{LC}_{90}$ values, together with their $95 \%$ confidence intervals, were determined through probit analysis of the mortality data (Finney 1971). In those cases in which the data were insufficient to calculate a $95 \%$ confidence interval, the lethal concentration was determined via logit transformation (Hafner et al. 1977).

\section{Results}

Bioactivity-directed fractionation

An ethanolic extract of the rhizome of J. elliptica, which had previously been shown to exhibit molluscicidal activity against $B$. glabrata, has been subjected to fractionation guided by activity against cercariae of $S$. mansoni (Table 1). Fractions containing compound 8 presented significant cercaricidal activities, and this component was isolated and identified as diethyl 4-phenyl-2,6-dimethyl-3,5-pyridinedicarboxylate.

Schistosomicidal activity in vitro

Table 2 shows that the in vitro exposure of $S$. mansoni adult worms to 8 resulted in the inhibition of movement and death, effects that were concentration dependent (Table 2). Following 4 days of exposure to 8 at a concentration of $50 \mu \mathrm{g} / \mathrm{mL}, 100 \%$
Table 1 Bioactivity-directed fractionation of an ethanolic extract of J. elliptica according to cercaricidal activity against $S$. mansoni

\begin{tabular}{|c|c|c|c|c|c|}
\hline \multirow[t]{2}{*}{ Additive } & \multirow{2}{*}{$\begin{array}{l}\text { Additive concentration } \\
(\mu \mathrm{g} / \mathrm{mL})\end{array}$} & \multicolumn{4}{|c|}{ Inhibition $^{\mathrm{a}}$ of cercaria after } \\
\hline & & $15 \mathrm{~min}$ & $30 \mathrm{~min}$ & $1 \mathrm{~h}$ & $2 \mathrm{~h}$ \\
\hline \multirow[t]{3}{*}{ Ethanolic extract } & 100 & - & \pm & + & + \\
\hline & 95 & - & \pm & + & + \\
\hline & 90 & - & - & - & - \\
\hline \multirow{3}{*}{$\begin{array}{l}\text { Ethyl acetate } \\
\text { fraction }\end{array}$} & 100 & - & - & + & + \\
\hline & 10 & - & - & + & + \\
\hline & 1 & - & - & - & - \\
\hline \multirow[t]{3}{*}{ Fraction $16-21^{\mathrm{b}}$} & 100 & - & + & + & + \\
\hline & 10 & - & + & + & + \\
\hline & 1 & - & - & - & + \\
\hline \multirow[t]{3}{*}{ Compound $8^{\mathrm{c}}$} & 100 & + & ++ & ++ & ++ \\
\hline & 10 & - & \pm & \pm & + \\
\hline & 1 & - & - & - & + \\
\hline
\end{tabular}

${ }^{\mathrm{a}}(++) 100 \%$ of larvae motionless at the bottom of the test tube, $(+)$ $\cong 90 \%$ of larvae motionless at the bottom of the test tube, $( \pm) \geq 50 \%$ of larvae motionless and/or at the bottom of the test tube and (-) lack of larvicidal activity with $>90 \%$ of larvae swimming

${ }^{\mathrm{b}}$ Fractions obtained following column chromatography

${ }^{\mathrm{c}}$ Diethyl 4-phenyl-2,6-dimethyl-3,5-pyridinedicarboxylate recrystallised from acetone

of adult schistosomes were observed to be dead and unpaired compared with control pairs that had been treated with solvent (RPMI 1640 medium containing 1\%DMSO) alone. Alterations to the schistosome tegument occasioned by treatment with 8 could be readily observed under the microscope and were manifested in the formation of vesicles that became apparent as early as $24 \mathrm{~h}$ after the introduction of the additive. Continued exposure led to vacuolisation followed by severe tegumental damage; the extent of which was proportional to the time of incubation and to the concentration of additive.

Miracicidal and cercaricidal activity

Compound 8 exhibited a significant concentration-dependent activity against $S$. mansoni cercariae but was totally inactive against the miracidia (Table 3). At a concentration of $4 \mu \mathrm{g} / \mathrm{mL}$, 8 completely immobilised cercariae after an exposure time of $30 \mathrm{~min}$.

Molluscicidal activity

A preliminary screen indicated that 8 was totally inactive against snail egg masses even at a concentration of $100 \mu \mathrm{g} /$ $\mathrm{mL}$ whilst, in the same bioassay, copper carbonate at $50 \mu \mathrm{g} /$ $\mathrm{mL}$ was $100 \%$ lethal. In contrast, detailed assays of the activity against adult snails of 8 in the concentration range 
Table 2 In vitro effects of diethyl 4-phenyl-2,6-dimethyl-3,5pyridinedicarboxylate (compound 8) isolated from the ethanol extract of the rhizome of J. elliptica against 56-day-old adult $S$. mansoni

${ }^{a}$ RPMI $1640+1 \%$ DMSO

\begin{tabular}{|c|c|c|c|c|c|c|}
\hline \multirow[t]{2}{*}{ Group } & \multirow{2}{*}{$\begin{array}{l}\text { Incubation } \\
\text { of period } \\
\text { (h) }\end{array}$} & \multirow[t]{2}{*}{$\begin{array}{l}\text { Dead worms } \\
\%\end{array}$} & \multicolumn{2}{|c|}{$\begin{array}{l}\text { Motor activity } \\
\text { reduction }(\%)\end{array}$} & \multicolumn{2}{|c|}{$\begin{array}{l}\text { Worms with tegumenta } \\
\text { alterations }(\%)\end{array}$} \\
\hline & & & Slight & Significant & Parcial & Extensive \\
\hline \multirow[t]{5}{*}{ Control $^{\mathrm{a}}$} & 24 & 0 & 0 & 0 & 0 & 0 \\
\hline & 48 & 0 & 0 & 0 & 0 & 0 \\
\hline & 72 & 0 & 0 & 0 & 0 & 0 \\
\hline & 96 & 0 & 0 & 0 & 0 & 0 \\
\hline & 120 & 0 & 0 & 0 & 0 & 0 \\
\hline \multirow[t]{5}{*}{ Praziquantel $10 \mu \mathrm{g} / \mathrm{mL}$} & 24 & 100 & 0 & 100 & 0 & 0 \\
\hline & 48 & 100 & 0 & 100 & 0 & 100 \\
\hline & 72 & 100 & 0 & 100 & 0 & 100 \\
\hline & 96 & 100 & 0 & 100 & 0 & 100 \\
\hline & 120 & 100 & 0 & 100 & 0 & 100 \\
\hline \multirow[t]{5}{*}{ Compound $810 \mu \mathrm{g} / \mathrm{mL}$} & 24 & 0 & 0 & & 0 & 0 \\
\hline & 48 & 0 & 0 & & 0 & 0 \\
\hline & 72 & 0 & 100 & & 0 & 0 \\
\hline & 96 & 0 & 25 & 75 & 0 & 0 \\
\hline & 120 & 0 & 0 & 100 & 0 & 0 \\
\hline \multirow[t]{5}{*}{$50 \mu \mathrm{g} / \mathrm{mL}$} & 24 & 0 & 0 & & 0 & 0 \\
\hline & 48 & 0 & 10 & 20 & 0 & 0 \\
\hline & 72 & 0 & 10 & 80 & 0 & 0 \\
\hline & 96 & 100 & 0 & 100 & 0 & 0 \\
\hline & 120 & 100 & 0 & 100 & 0 & 0 \\
\hline \multirow[t]{5}{*}{$100 \mu \mathrm{g} / \mathrm{mL}$} & 24 & 0 & 0 & 0 & 0 & 0 \\
\hline & 48 & 65 & 0 & 100 & 100 & 0 \\
\hline & 72 & 85 & 0 & 100 & 100 & 0 \\
\hline & 96 & 100 & 0 & 100 & 0 & 100 \\
\hline & 120 & 100 & 0 & 100 & 0 & 100 \\
\hline \multirow[t]{5}{*}{$200 \mu \mathrm{g} / \mathrm{mL}$} & 24 & 100 & 0 & 100 & 0 & 100 \\
\hline & 48 & 100 & 0 & 100 & 0 & 100 \\
\hline & 72 & 100 & 0 & 100 & 0 & 100 \\
\hline & 96 & 100 & 0 & 100 & 0 & 100 \\
\hline & 120 & 100 & 0 & 100 & 0 & 100 \\
\hline
\end{tabular}

$10-50 \mu \mathrm{g} / \mathrm{mL}$ were performed, and the $\mathrm{LC}_{10}, \mathrm{LC}_{50}$ and $\mathrm{LC}_{99}$ values was determined through probit analysis (Table 4).

\section{Discussion}

This study was performed to evaluate in vitro the antischistosomal effect of penta-substituted pyridine 8 for controlling schistosomiasis. In the last decades, plant extracts were widely used for the treatment of schistosoma infection (Molgaard et al. 2001).

The penta-substituted pyridine 8 has already been reported to possess strong multidrug resistance reversal activity (Marquez et al. 2005). In the present study, 8 was assayed for potential schistosomicidal, miracidicidal, cercaricidal and molluscicidal properties.
The lethal concentration against S. mansoni of 8 was fourfold lower than that of the quassinoid longilactone isolated from the leaves of Eurycoma longifolia (Jiwajinda et al. 2002). This compound lead to the separation of all couple worms and extensive disruption on their teguments, such as sloughing. Similar results were presented by solasonine $(50 \mu \mathrm{M})$, solamargine (32 and $50 \mu \mathrm{M}$ ) and equimolar mixture of glycoalkaloids $(20,32$ and $50 \mu \mathrm{M})$ steroidal alkaloids from Solanum lycocarpum fruits (Miranda et al. 2012). The action on the tegument is important since this protects the schistosome against attack by the immune system of the host and is also involved in nutrient absorption and secretory functions; it is considered to be an important target for anti-schistosomal drugs (Utzinger et al. 2000).

Studies with phloroglucinol compounds, obtained from the rhizomes of Dryopteris species against $S$. mansoni adult 
Table 3 Activity of diethyl 4phenyl-2,6-dimethyl-3,5pyridinedicarboxylate (8) against miracidia and cercariae of S. mansoni

${ }^{a}(++) 100 \%$ of larvae motionless at the bottom of the test tube, $(+)$ $\cong 90 \%$ of larvae motionless at the bottom of the test tube, $( \pm) \geq 50 \%$ of larvae motionless and/or at the bottom of the test tube and (-) lack of larvicidal activity with $>90 \%$ of larvae swimming

\begin{tabular}{|c|c|c|c|c|c|c|}
\hline \multirow[t]{2}{*}{ Larvae } & \multirow[t]{2}{*}{ Additive (concentration $\mu \mathrm{g} / \mathrm{mL}$ ) } & \multicolumn{4}{|c|}{ Inhibition ${ }^{\mathrm{a}}$ of larvae after } & \multirow{2}{*}{$\begin{array}{l}\mathrm{LC}_{100} \\
(\mu \mathrm{g} / \mathrm{mL})\end{array}$} \\
\hline & & $15 \mathrm{~min}$ & $30 \mathrm{~min}$ & $1 \mathrm{~h}$ & $2 \mathrm{~h}$ & \\
\hline \multirow[t]{5}{*}{ Miracidia } & VIII (100) & - & - & - & - & \multirow[t]{3}{*}{ Inactive } \\
\hline & VIII (10) & - & - & - & - & \\
\hline & VIII (1) & - & - & - & - & \\
\hline & Niclosamide (3) & ++ & ++ & ++ & ++ & Active \\
\hline & Dechlorinated water containing $1 \%$ DMSO & - & - & - & - & Inactive \\
\hline \multirow[t]{8}{*}{ Cercariae } & VIII (8) & + & ++ & ++ & ++ & \multirow[t]{6}{*}{2.0} \\
\hline & VIII (6) & + & ++ & ++ & ++ & \\
\hline & VIII (4) & + & ++ & ++ & ++ & \\
\hline & VIII (2) & \pm & + & + & + & \\
\hline & VIII (1.5) & - & - & - & - & \\
\hline & VIII (1.0) & - & - & - & - & \\
\hline & Niclosamide (3) & ++ & ++ & ++ & ++ & \multirow[t]{2}{*}{ Active } \\
\hline & Dechlorinated water containing $1 \%$ DMSO & - & - & - & - & \\
\hline
\end{tabular}

worms, also showed similar results, but with a faster action. All worm pairs were dead after $24 \mathrm{~h}$ of incubation with aspidin 25 to $100 \mu \mathrm{M}$, flavaspidic acid 50 and $100 \mu \mathrm{M}$, methylenebis-aspidinol $100 \mu \mathrm{M}$ and desaspidin 25 to $100 \mu \mathrm{M}$ (Magalhães et al. 2010).

Infection with $S$. mansoni occurs when the cercaria penetrates the body of man through intact skin. Therefore, to prevent such penetration is also a potential way of controlling infection (De-Carvalho et al. 1998). Activity presented by compound 8 was considerably stronger than that presented by the mixture of robustic acid, alpinum isoflavone and dimethylalpinum isoflavone isolated from the seeds of Milletia thonningii, which was lethal to cercariae at a concentration of $50 \mu \mathrm{g} / \mathrm{mL}$ after an exposure time of $30 \mathrm{~min}$ (Lyddiard et al. 2002). In contrast, however, the synthetic molluscicide niclosamide when applied at a concentration of $0.05 \mu \mathrm{g} / \mathrm{mL}$ induced 87 and $69 \%$ mortality, respectively, in cercariae and miracidia of $S$. mansoni following $2 \mathrm{~h}$ of exposure (De-Carvalho et al. 1998).

Whilst Biomphalaria spp. control by molluscicides is one of the main strategies to reduce the snail population in infected areas, there are few effective molluscicides commercially available. Therefore, natural products may be considered as potentially useful and safe molluscicides (Miyasato et al. 2012). In this research, the compound 8 , in comparison with the main components of the ethanolic extract of J. elliptica by Santos and Sant'Ana (1999), showed an activity $\left(\mathrm{LC}_{90}=\right.$ $36.43 \mu \mathrm{g} / \mathrm{mL}$ ) lower than that of jatrophone $\left(\mathrm{LC}_{90}=8.91 \mu \mathrm{g}\right.$ / $\mathrm{mL}$ ) but much higher than those of the jatropholones $\mathrm{A}$ and $\mathrm{B}$ $\left(\mathrm{LC}_{90}=206.16 \mu \mathrm{g} / \mathrm{mL}\right)$. The molluscicidal activity of 8 is significantly lower than those of niclosamide $\left(\mathrm{LC}_{100}=\right.$ $1.5 \mu \mathrm{g} / \mathrm{mL}$ ), which is recommended by the World Health Organization (WHO 1993) for large scale use in schistosomiasis is control programmes.

Table 4 Bioactivity of diethyl 4-phenyl-2,6-dimethyl-3,5-pyridinedicarboxylate (8) against B. glabrata adults

\begin{tabular}{lllllll}
\hline Additive & $\begin{array}{l}\text { Diameter of snails } \\
(\mathrm{mm})\end{array}$ & $\begin{array}{l}\text { Concentration } \\
(\mu \mathrm{g} / \mathrm{mL})\end{array}$ & $\begin{array}{l}\text { Mortality } \\
(\%)\end{array}$ & $\mathrm{LC}_{10}(\mu \mathrm{g} / \mathrm{mL})^{\mathrm{a}}$ & $\mathrm{LC}_{50}(\mu \mathrm{g} / \mathrm{mL})^{\mathrm{a}}$ & $\mathrm{LC}_{90}(\mu \mathrm{g} / \mathrm{mL})^{\mathrm{a}}$ \\
\hline Compound $8^{\mathrm{b}}$ & $17-24$ & 50 & 100 & $7.57 \mathrm{CI}_{95}=4.57-9.97$ & $16.60 \mathrm{CI}_{95}=13.52-19.59$ & $36.43 \mathrm{CI}_{95}=29.45-52.21$ \\
& & 30 & 83 & & \\
& 20 & 50 & & \\
& & 10 & 26 & & \\
Copper carbonate & $21-24$ & 50 & 0 & & & \\
Dechlorinated water & $21-24$ & & & & \\
containing 0.1 \% & & & & & \\
DMSO & & & & & \\
\hline
\end{tabular}

${ }^{\text {a }}$ Determined after $96 \mathrm{~h}$ incubation

${ }^{\mathrm{b}}$ Diethyl 4-phenyl-2,6-dimethyl-3,5-pyridinedicarboxylate 


\section{Conclusion}

Currently, chemotherapy is the most widely employed method for the control of schistosomiasis, although treatment is based on just a few available drugs. Recently, a diminished response to praziquantel (the drug of choice for the treatment of the disease) has been reported suggesting the appearance of nonsusceptible strains of the parasite. For this reason, the search for new anti-schistosomal drugs, particularly those deriving from natural sources, has attained a greater importance. In this context, the present study has demonstrated that diethyl 4phenyl-2,6-dimethyl-3,5-pyridinedicarboxylate (8), derived from the rhizome of $J$. elliptica, is highly active against adult S. mansoni and free-living cercariae and against the adult snail host $B$. glabrata. In contrast, 8 was inactive against the miracidia of the schistosome and against egg masses of the snail. However, further studies, including in vivo assays, are necessary to fully determine the potential of this compound for the development of new therapeutics to treat schistosomiasis.

Acknowledgments The authors are grateful to the Conselho Nacional de Desenvolvimento Científico e Tecnológico (CNPq), Fundação de Auxílio à Pesquisa de Alagoas (FAPEAL), IMSEAR (Instituto do Milênio do Semi-Árido) and Fundação Capacitação de Pessoal de Nível Superior (CAPES) for the scholarships and financial support in respect of this study.

Open Access This article is distributed under the terms of the Creative Commons Attribution License which permits any use, distribution, and reproduction in any medium, provided the original author(s) and the source are credited.

\section{References}

Abdul-Ghani R, Loutfy N, Sheta M, Hassan A (2011) Artemether shows promising female schistosomicidal and ovicidal effects on the Egyptian strain of Schistosoma mansoni after maturity of infection. Parasitol Res 108:1199-1205. doi:10.1007/s00436-010-2163-9

De-Carvalho RR, Maldonado A Jr, Oliveira-Filho EC, Ribeiro AC, Paumgartten FJR, Rey L (1998) Effects of Euphorbia milli látex on Schistosoma mansoni eggs, miracidia and cercariae. Mem Inst Oswaldo Cruz 93:235-237. doi:10.1590/S0074-02761998000700042

Elango G, Rahuman AA (2011) Evaluation of medicinal plant extracts against ticks and fluke. Parasitol Res 108:513-519

El-Beshbishi SN, Taman A, El-Malky M, Azab MS, El-Hawary AK, ElTantawy DA (2013) First insight into the effect of single oral dose therapy with artemisinin-naphthoquine phosphate combination in a mouse model of Schistosoma mansoni infection. Int J Parasitol 43(7):521-30. doi:10.1016/j.ijpara.2013.01.007

Ferreira JFS, Peaden P, Keiser J (2011) In vitro trematocidal effects of crude alcoholic extracts of Artemisia annua, A. absinthium, Asimina triloba and Fumaria officinalis. Parasitol Res 109:1585-1592. doi: 10.1007/s00436-011-2418-0

Finney DJ (1971) Probit analysis, 3rd edn. Cambridge University, Cambridge, 333p

Ghosh S, Debnath S, Hazra S, Hartung A, Thomale K, Schultheis M, Kapkova P, Schurigt U, Moll H, Holzgrabe U, Hazra B (2011)
Valeriana wallichii root extracts and fractions with activity against Leishmania spp. Parasitol Res 108:861-871

Goulart MOF, Sant'Ana AEG, Lima RA, Cavalcante SH (1993) Fitoconstituintes químicos isolados de Jatropha elliptica. Atribuição dos deslocamentos químicos dos átomos de carbono e hidrogênio dos diterpenos jatrofolonas A e B. Quim Nova 16:95-100

Hafner E, Heiner E, Noack E (1977) Mathematical analysis of concentrationresponse relationship. Method for the evaluation of the ED50 and the number of binding sites per receptor molecule using the logit transformation. Arzneimittelforschung 27(10):1871-1873

Jiwajinda S, Santisopasri V, Murakami A, Sugiyama H, Gasquet M, Riad E, Balansard G, Ohigashi H (2002) In vitro anti-tumor promoting and anti-parasitic activities of the quassinoids from Eurycoma longifolia, a medicinal plant in Southeast Asia. J Ethnopharmacol 82(1):55-58, Erratum in: J Ethnopharmacol. 2003 85(1):173

Kamel EG, El-Emam MA, Mahmoud SSM, FoudaFM BFE (2010) Attenuation of Schistosoma mansoni cercarial infectivity to albino mice by methanol extract of some plant species. Pestic Biochem Physiol 98:342-348. doi:10.1016/j.pestbp.2010.07.007

Katz N, Peixoto SV (2000) Análise crítica da estimativa do número de portadoras de esquistossomose mansônica no Brasil. Rev Soc Bras Med Trop 33(3):303-308

Koné WM, Vargas M, Keiser J (2012) Anthelmintic activity of medicinal plants used in Côte d'Ivoire for treating parasitic diseases. Parasitol Res 110:2351-2362. doi:10.1007/s00436-011-2771-Z

Li H, Wang W, Qu G, Li Y, Tao Y, Xing Y, Wang X, Dai Y, Wei J, Dai J, Coles GC, Liang Y (2011) Effect of the in vivo activity of dihydroartemisinin against Schistosoma mansoni infection in mice. Parasitol Res. doi:10.1007/s00436-011-2692-x

Lima MRF, Luna JS, Santos AF, Andrade MCC, Sant'Ana AEG, Genet JP, Marquez B, NeuvilleLuc MN (2006) Anti-bacterial activity of some Brazilian medicinal plants. J Ethnopharmacol 105:137-147

Luna JS, Santos AF, Lima MRF, Omena MC, Mendonça FAC, Sant'Ana AEG, Moreau NJ (2005) A study of the larvicidal and molluscicidal activities of some medicinal plants from northeast of Brazil. J Ethnopharmacol 97(2):199-206

Lyddiard JRA, Whitfield PJ, Bartlett A (2002) Anti-schistosomal bioactivity of isoflavonoids from Millettia thonningii (Leguminosae). Int J Parasitol 88(1):163-70

Magalhães LG, Machado CB, Morais ER, Moreira EB, Soares CS, da Silva SH, Da Silva Filho AA, Rodrigues V (2009) In vitro schistosomicidal activity of curcumin against Schistosoma mansoni adult worms. Parasitol Res 104(5):1197-1201

Magalhães LG, Kapadia GJ, da Silva Tonuci LR, Caixeta SC, Parreira NA, Rodrigues V, da Silva Filho AA (2010) In vitro schistosomicidal effects of some phloroglucinol derivatives from Dryopteris species against Schistosoma mansoni adult worms. Parasitol Res 106(2): 395-401. doi:10.1007/s00436-009-1674-8

Marquez B, Neuville L, Moreau NJ, Genet JP, dos Santos AF, Caño de Andrade MC, Sant'Ana AE (2005) Multidrug resistance reversal agent from Jatropha elliptica. Phytochemistry 66(15):1804-11

Mercer JG, Chapell LM (1985) Schistosoma mansoni: effect of maintenance in vitro on the physiology and biochemistry of adult worms. Parasitology 2:339-49

Miranda MA, Magalhães LG, Tiossi RFJ, Kuehn CC, Oliveira LGR, Rodrigues V, McChesney JD, Bastos JK (2012) Evaluation of the schistosomicidal activity of the steroidal alkaloids from Solanum lycocarpum fruits. Parasitol Res 111:257-262. doi:10.1007/s00436012-2827-8

Miyasato PA, Kawano T, Freitas JC, Berlinck RGS, Nakano E, Tallarico LF (2012) Molluscicidal activity of some marine substances against the snail Biomphalaria glabrata (Mollusca, Planorbidae). Parasitol Res 110(5):1873-1879. doi:10.1007/s00436-011-2712-x

Mohamed AZ, Metwally NM, Mahmoud SS (2005) Lativa seeds against Schistosoma mansoni different stages. Mem Inst Oswaldo Cruz 100(2):205-211 
Molgaard P, Nielsen SB, Rasmussen DE, Drummond RB, Makaza N, Andreassen J (2001) Anthelmintic screening of Zimbabwean plants traditionally used against schistosomiasis. J Ethnopharmacol 74 : 257-264

Mostafa OMS, Eid RA, Adly MA (2011) Antischistosomal activity of ginger (Zingiber officinale) against Schistosoma mansoni har-bored in C57 mice. Parasitol Res 109:395-403. doi:10.1007/s00436-0112267-x

Pontin K, Da Silva Filho AA, Santos FF, Silva MLA, Cunha WR, Nanayakkara NPD, Bastos JK, Albuquerque S (2008) In vitro and in vivo antileishmanial activities of a Brazilian green propolis extract. Parasitol Res 103:487-492

Rollemberg CVV, Santos CMB, Silva MMBL et al (2011) Epidemiological characteristics and geographical distribution of schistosomiasis and geohelminths, in the State of Sergipe, according to data from the Schistosomiasis Control Program in Sergipe. Rev Soc Bras Med Trop 44:91-96. doi:10.1590/ S0037-86822011000100020

Sabandar CW, Ahmat N, Jaafar FM, Sahidin I (2013) Medicinal property, phytochemistry and pharmacology of several Jatropha species (Euphorbiaceae): a review. Phytochemistry 85:7-29. doi:10.1016/j. phytochem.2012.10.009

Santos AF, Sant'Ana AEG (1999) Molluscicide activity of the diterpenoids jatrophone and jatropholones A and B isolated from Jatropha elliptica(Pohl) Muell. Arg Phytoth Res 13: 660-664

Santos AF, Sant'Ana AEG (2001) Molluscicidal properties of some species of Annona. Phytomedicine 8:115-120

Santos AF, Simone CA, Sant'Ana AEG, Pereira MA, Malta VRS (2005) Crystal structure of diethyl 4-phenyl-2,6-dimethyl-3,5- pyridinedicarboxylate, $\mathrm{C}_{19} \mathrm{H}_{21} \mathrm{NO}_{4}$, a multidrug resistance reversal agent from Jatropha elliptica. Z Kristallogr 611-612

Santos AF, Azevedo DP, Santos Mata Rda C, Mendonça DI, Sant'Ana AE (2007) The lethality of Euphorbia conspicua to adults of Biomphalaria glabrata, cercaria of Schistosoma mansoni and larvae of Artemia salina. Bioresour Technol 98(1):135-139. doi:10.1016/j. biortech.2005.11.020

Santos AF, Cavada BS, Rocha BA, Nascimento KS, Sant'Ana AE (2010) Toxicity of some glucose/mannose-binding lectins to Biomphalaria glabrata and Artemia salina. Bioresour Technol 101(2):794-798. doi:10.1016/j.biortech.2009.07.062

Shukla S, Singh VK, Singh DK (2006) The effect of single, binary, and tertiary combination of few plant derived molluscicides alone or in combination with synergist on different enzymes in the nervous tissues of the freshwater snail Lymnaea (Radix) acuminata (Lamark). Pestic Biochem Physiol 85:167-173. doi:10.1016/j. pestbp.2006.01.003

Teixeira T, Rosa JS, Rainha N, Baptista J, Rodrigues A (2012) Assessment of molluscicidal activity of essential oils from five Azorean plants against Radix peregra (Müller, 1774). Chemosphere 87(1):1-6. doi: 10.1016/j.chemosphere.2011.11.027

Utzinger J, N'Goran EK, N'Dri A, Lengeler C, Xiao S, Tanner M (2000) Oral artemether for prevention of Schistosoma mansoni infections: randomized controlled trial. Lancet 355(9212):1320-1325

WHO (1993) The control of schistosomiasis. WHO Tech. Rept. Ser. 830, Geneva. 830:1-86. http://www.ncbi.nlm.nih.gov/pubmed/8322462. Accessed 21 Jan 2013

WHO (2005) Report of the Scientific Working Group Meeting on Schistosomiasis. http://whqlibdoc.who.int/hq/2006/TDR_SWG_ 07_eng.pdf. Accessed 21 Jan 2013 